\title{
The new method of 1,2-epoxy-3-butanol production over titanium silicalite catalysts
}

\author{
Joanna Wajzberg, Agnieszka Wróblewska
}

Szczecin University of Technology, Institute of Organic Chemical Technology, ul. Pułaskiego 10, 70-322 Szczecin, Poland, e-mail: jwajzberg@ps.pl

The results of 1-butene-3-ol (1B3O) epoxidation over the titanium silicalite catalysts: TS-1, Ti-Beta, TiMCM-41 has been presented. The optimal parameters obtained for the individual catalyst were compared. The main functions describing the process were: the selectivity of transformation to 1,2-epoxy-3-butanol $(1,2 \mathrm{E} 3 \mathrm{~B})$ in relation to $1 \mathrm{~B} 3 \mathrm{O}$ consumed, the conversions of $1 \mathrm{~B} 3 \mathrm{O}$ and hydrogen peroxide and the selectivity of the transformation to organic compounds in relation to the $\mathrm{H}_{2} \mathrm{O}_{2}$ consumed. The main product of the epoxidation process was 1,2-epoksy-3-butanol, the chemical compounds having a lot of applications.

Keywords: 1,2-epoxy-3-butanol, liquid phase epoxidation, TS-1, Ti-Beta, Ti-MCM-41.

Presented at VII Conference Wasteless Technologies and Waste Management in Chemical Industry and Agriculture, Międzyzdroje, 12 - 15 June, 2007.

\section{INTRODUCTION}

In the channels of titanium silicalite catalysts 5membered active compounds, in which: titanium (the active centre of catalyst), methanol (solvent) and hydrogen peroxide take part, are formed during epoxidation. It enables the transfer of oxygen from the $\mathrm{H}_{2} \mathrm{O}_{2}$ molecule to the double bond of allyl alcohol and it causes epoxide compounds to be formed.

The process of 1-buten-3-olu epoxidation with hydrogen peroxide over titanium silicalite catalysts is ecologically friendly and safe. Not only methanol and 1B3O but also the catalyst can used in the process many times. The traditional methods of the epoxide synthesis rely on the intramolecular cyclization of chlorohydrins with the use of the aqueous alkaline solutions or on the alkene epoxidation with per-acids. There have been developed new directions in the synthesis of this group of compounds in recent years. They rely on the elimination of organic wastes, the by-products difficult to manage and on the limitation of the quantity of the generated sewage. These objectives were archived through the catalytic processes of the oxidation of olefinic compounds with organic hydroperoxides or hydrogen peroxide. Hydrogen peroxide is considered to be the most ecologically oxidizing agent in the synthesis processes.

1,2-Epoksy-3-butanol (1,2E3B) which is formed in the process is a valuable compound for the pharmaceutical industry.<smiles>CC(O)C1CO1</smiles>

The presence of two very reactive groups (epoxy and secondary hydroxyl) in the molecule of this compound means that it can be a raw material for the production of many intermediates and products of chemical industrial with a wide range of applications. It makes studying the technology of obtaining this compound a very important issue.

$1,2 \mathrm{E} 3 \mathrm{~B}$ is an intermediate in the synthesis of treonine (hydroxyaminoacid) ${ }^{\mathbf{1}}$ which has a significant influence on the production of colagene, elastin and tooth enamel. Moreover, it participates in fat metabolism, improves the function of the digestive system, metabolism and assimilation of food. L-treonine is included in the composition of actynomycine $\mathrm{D}$, a well-known antibiotic, which exhibits a large antibacterial and antitumor activity. In 1954 actynomycine $\mathrm{D}$ was introduced to the clinical therapy as an antitumor drug and was it was found that it is very effective in the therapy of many kinds of tumor. It is also widely used in biochemistry and the molecular biology ${ }^{2}$.

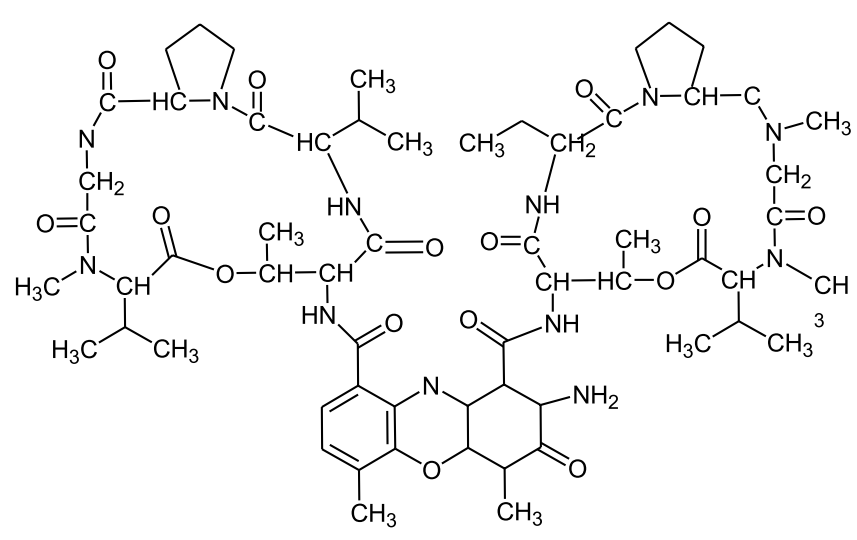

Actynomycine D structure

(2S, 3R)-1,2-Epoxy-3-butanol is used in the synthesis of drugs under the name Epothilone $\mathrm{B}^{3}$ and $\mathrm{A}^{4}$. Epothilone $\mathrm{B}$ is designed by a symbol EPO906 and is currently in clinical studies. EPO906 is macrolide which was isolated from bacterial culture Sorangium Cellulosum. It was demonstrated that EP0906 blocks the division of cancer cells and is a more efficient in action than taxol (the drug used in chemotherapy in the case of becoming ill with the cancer of ovary, ripple and lungs) ${ }^{5}$.

Enantioselective epoxidation of $1 \mathrm{~B} 3 \mathrm{O}$ in the presence of D-(-)-tartrate produces (2S,3R)-1,2-epoksy-3-butanol, which was employed in chiral syntheses of 2,5dideoxyribose and a segment of the boromycine structure, the antibiotic exhibiting the antitumor action. There are also performed studies on boromycine activity agains bacterial gram-dodatnim, fungus and protozoa ${ }^{6}$. 


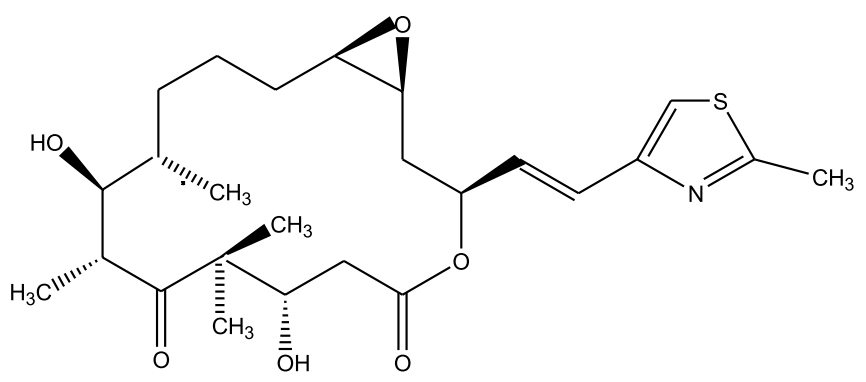

Epothilone A

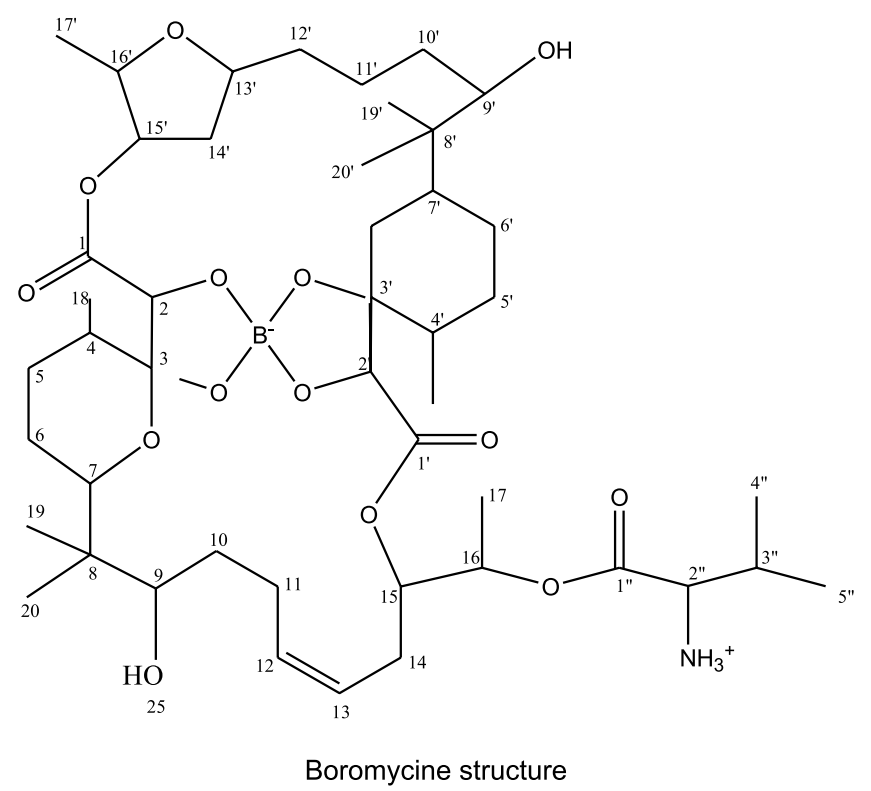

\section{EXPERIMENTAL}

There were used in the epoxidation process the following raw materials: 1-butene-3-ol (1B3O) (pure 98\%, Fluka), hydrogen peroxide (30 wt $\%$, POCh Gliwice), methanol (analytical grade, POCh, Gliwice) and catalyst titanium-silicalite TS-1, Ti-Beta, Ti-MCM-41 prepared in Institute of Organic Chemical Technology. The TS-1 catalyst was prepared with the method of Thangaraj et al. ${ }^{7}, \mathrm{Ti}-$ Beta catalyst was prepared with the method of Camblor et al. ${ }^{8}$ and Ti-MCM-41 catalyst was prepared with the method of Grün et al. ${ }^{9}$ The epoxidation of $1 \mathrm{~B} 3 \mathrm{O}$ was carried out under atmospheric pressure. In the synthesis a glass reactor equipped with a reflux condenser, a thermometer, a mechanical stirrer and a dropper were used. The reactor was charged successively with a catalyst, $1 \mathrm{~B} 3 \mathrm{O}$ and methanol. Hydrogen peroxide was added dropwise with a vigorous stirring at the reaction temperature. During the epoxidation of $1 \mathrm{~B} 3 \mathrm{O}$ over titanium silicalite catalysts the influence of the following parameters: temperature 0 $60^{\circ} \mathrm{C}$, the molar ratio of $1 \mathrm{~B} 3 \mathrm{O} / \mathrm{H}_{2} \mathrm{O}_{2}$ 0.5:1-5:1, methanol concentration $5-90 \mathrm{wt} \%$, TS-1 concentration $0.1-5.0$ $\mathrm{wt} \%$ and the reaction time $0.5-5.0 \mathrm{~h}$ was investigated. The products were analyzed quantitatively using a gas chromatograph Focus with a flame-ionization detector (FID) and using a capillary column Quadrex (30 m x $250 \mu \mathrm{m} \times 0,25 \mu \mathrm{m})$. The parameters of chromatographic separation were as follows: the pressure of helium $-35 \mathrm{kPa}$, the detector temperature $-250^{\circ} \mathrm{C}$ and the temperature of the sample chamber $-150^{\circ} \mathrm{C}$. The thermostat temperature was programmed in the following way: isothermally $40^{\circ} \mathrm{C}$ for $3 \mathrm{~min}$, followed by an increase at the rate $10^{\circ} \mathrm{C} / \mathrm{min}$, isothermally $250^{\circ} \mathrm{C}$ for $5 \mathrm{~min}$, and finally cooling to $40^{\circ} \mathrm{C}$.

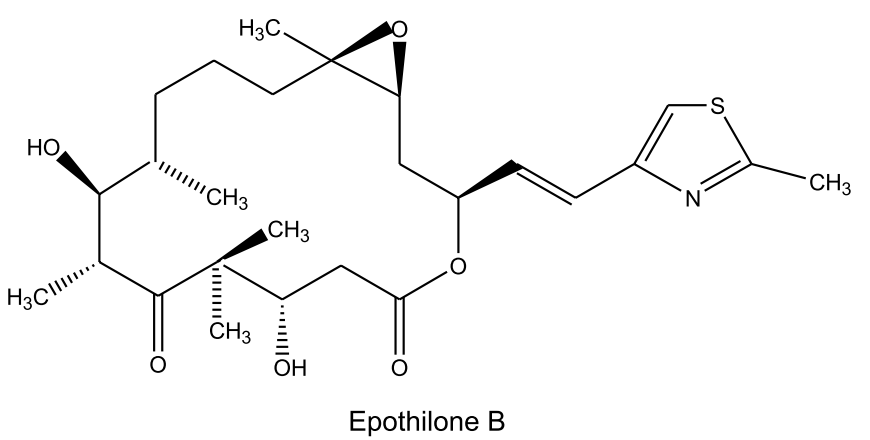

The concentration of the unreacted hydrogen peroxide was determined iodometrically10. After performing the mass balance for each of the synthesis, the main functions characterizing the process: the selectivity of the transformation to $1,2 \mathrm{E} 3 \mathrm{~B}$ in relation to the $1 \mathrm{~B} 3 \mathrm{O}$ consumed, the conversions of $1 \mathrm{~B} 3 \mathrm{O}$ and hydrogen peroxide, and the selectivity of the transformation to organic compounds in relation to hydrogen peroxide consumed, were determined.

\section{RESULTS}

The principal and side reactions proceeding during the epoxidation of $1 \mathrm{~B} 3 \mathrm{O}$ over titanium silicalite are presented below - scheme 1 .

1,2-Epoxy-3-butanol are the main products in this process. As a result of the attack of the water molecule, breaking of the epoxide ring and the formation of 1,2,3butanetriol proceeds. In the epoxidation process, for example at the higher temperatures, are also formed ethers, the products of methanolysis and polymers. All the byproducts were identified by the GC/MS but only: 1,2,3butanetriol, trimethoxybutane, 1,2-epoxy-3-methoxybutane and 3-(3-methyl-1-propene)-3-methyl-1,2-epoxypropane ether were quantitatively established (the main by-product was 1,2,3-butanetriol). The other by-products found in the post-reaction mixture were in a trace amount. The variety of the products formed during the $1 \mathrm{~B} 3 \mathrm{O}$ epoxidation indicates that the selection of the conditions of the process operation is very important. It is also important to achieve the high conversion of $\mathrm{H}_{2} \mathrm{O}_{2}$, because the presence of the unreacted $\mathrm{H}_{2} \mathrm{O}_{2}$ creates an additional problem during the separation of the epoxidation products. The separation can be performed most favorably using the rectification method. The presence of $\mathrm{H}_{2} \mathrm{O}_{2}$ is here harmful due to the possibility of its decomposition in an uncontrollable way. In connection with this, $\mathrm{H}_{2} \mathrm{O}_{2}$ should be removed e.g. by a slow heating of the postreaction mixture. However, this leads to a partial loss of the product as a result of polymerization. The chemical methods of the decomposition of the unreacted hydrogen peroxide (e.g. by means of an aqueous solution of sodium bisulfite) enhance the costs of process operation. The achievement of a high selectivity of the transformation to the organic compounds in relation to the consumed $\mathrm{H}_{2} \mathrm{O}_{2}$ is also important.

Table 1 presents the optimum conditions for the epoxidation of $1 \mathrm{~B} 3 \mathrm{O}$ over the individual catalysts and the values of the functions, which describe this process the best: the selectivity of the transformation to $1,2 \mathrm{E} 3 \mathrm{~B}$ in relation to the $1 \mathrm{~B} 3 \mathrm{O}$ consumed, the selectivity of the transformation to the organic compounds in relation to 


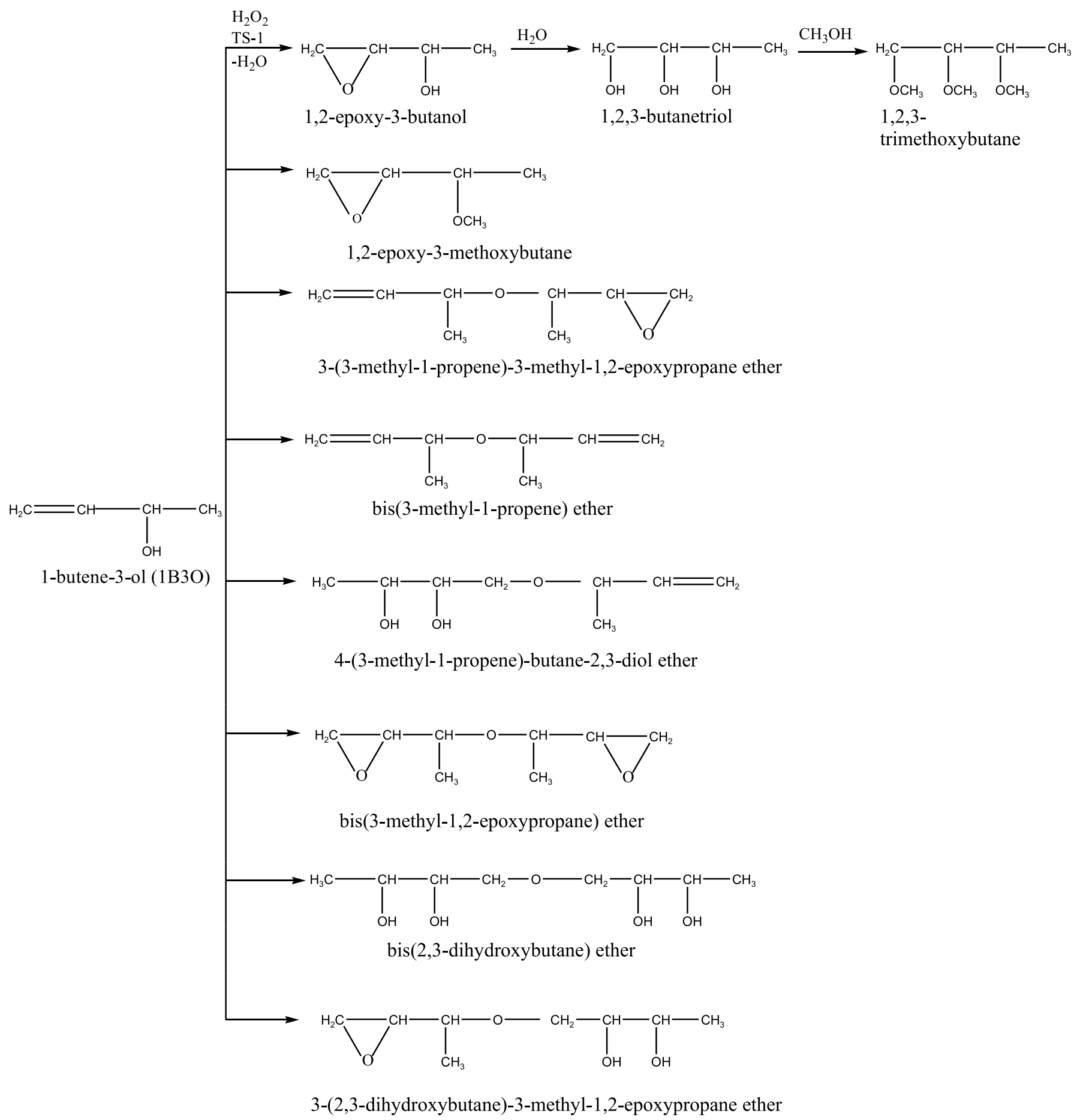

Scheme 1. The products of $1 \mathrm{~B} 3 \mathrm{O}$ epoxidation

Table 1. The optimal parameters of $1 \mathrm{~B} 3 \mathrm{O}$ epoxidation over the catalysts: TS-1, Ti-Beta, Ti-MCM-41 and the values of the main function describing the process

\begin{tabular}{|c|c|c|c|}
\hline & TS-1 & Ti-Beta & Ti-MCM-41 \\
\hline - Temperature $\left[{ }^{\circ} \mathrm{C}\right]$ & 20 & 20 & 10 \\
\hline$-1 \mathrm{~B} 3 \mathrm{O} / \mathrm{H}_{2} \mathrm{O}_{2}$ molar ratio & $1: 1$ & $1: 1$ & $1: 1$ \\
\hline - Methanol concentration [wt \%] & 80 & 40 & 40 \\
\hline - Catalysts concentration [wt \%] & 3.0 & 3.0 & 3.0 \\
\hline - Reaction time $[\mathrm{h}]$ & 3 & 5 & 5 \\
\hline Selectivity 1,2E3B/1B3O [mol \%] & 100 & 69 & 67 \\
\hline Conversion of $1 \mathrm{~B} 30$ [mol \%] & 83 & 72 & 88 \\
\hline Conversion of $\mathrm{H}_{2} \mathrm{O}_{2}$ [mol \%] & 97 & 98 & 94 \\
\hline Selectivity org. compounds $/ \mathrm{H}_{2} \mathrm{O}_{2}$ [mol \%] & 87 & 74 & 88 \\
\hline
\end{tabular}


the $\mathrm{H}_{2} \mathrm{O}_{2}$ consumed and the conversions of $1 \mathrm{~B} 3 \mathrm{O}$ and $\mathrm{H}_{2} \mathrm{O}_{2}$.

\section{CONCLUSION}

The process of 1,2E3B obtaining during the epoxidation of $1 \mathrm{~B} 3 \mathrm{O}$ by $30 \mathrm{wt} \%$ hydrogen peroxide over TS- 1 , TiBeta and Ti-MCM-41 proceeds best at low temperature about $10-20^{\circ} \mathrm{C}$, at the equimolar ratio at $1 \mathrm{~B} 3 \mathrm{O} / \mathrm{H}_{2} \mathrm{O}_{2}$, the solvent concentration of $40-80 \mathrm{wt} \%$, the catalyst concentration of $3 \mathrm{wt} \%$ and the reaction time $4-5 \mathrm{~h}$. It results from Table 1 that for the epoxidation of $1 \mathrm{~B} 3 \mathrm{O}$ the microporous catalyst TS- 1 is the best. The highest selectivity of the transformation to $1,2 \mathrm{E} 3 \mathrm{~B}(100 \mathrm{~mol} \%)$ was achieved over this catalyst. It has an impact on the higher reactivity of the TS-1 catalyst in comparison with the microporous Ti-Beta catalyst and the mesoporous $\mathrm{Ti}$ MCM-41 catalyst. The Ti-Beta catalyst generally differs from the TS- 1 and Ti-MCM- 41 catalysts. Their structure, apart from ions silicon and titanium, includes also ions aluminum. By comparing the results of the epoxidation over Ti-Beta and Ti-MCM-41 catalysts we can say, that in spite of the different structure the catalysts they have similar reactivity. The presented method of epoxidation is an example of new trends in contemporary fine chemistry. It also fulfills the requirements of „green chemistry”. It is the ecologically friendly method using as an oxidizing agent „green oxidant” - hydrogen peroxide. It is worth noting that water is the only product of transformation hydrogen peroxide. In addition, the technology of the production of $\mathrm{H}_{2} \mathrm{O}_{2}$, is well developed and thus it is now cheap and easily available. Solvent (methanol) and unreacted organic raw material can be easy distillated and returned to the process. The used catalysts can be easily separated from the post-reaction mixture and repeatedly used in the syntheses. Owing to the fact that the epoxidation proceeds under mild conditions, the number of the byproducts was limited to the minimum. It allows to save energy which is needed for the utilization of the by-products.

\section{LITERATURE CITED}

(1) Jung M. E., Jung Y. H.: Tetrahed. Lett., Rapid synthesis of $\beta$-hydroxy- $\beta$-amino acids, such as L-threonine, $B$ hydroxyphenylalanine, and $\beta$-hydroxyleucine, via an application of the Sharpless asymmetric epoxidation, 30, 1989, 6637.

(2) Piro A. J., Taylor C. C., Belli J. A.: Interactions between radiation and drug damage in mammalian cells. I. Delayed expression of actinomycin D/x-ray effects in exponential and plateau phase cells, Radiat. Res., 1975, 63, 346.

(3) Valluri M., Hindupur R. M, Bijoy P., Labadie G., Avery M. A.: Total synthesis of epothilone B, Org. Lett., 2001, 23, 3607.

(4) Hindupur R. M., Panicker B., Valluri M., Avery M. A.: Total synthesis of epothilone A, Tetrahed. Lett., 2001, 42, 7341.

(5) Kąkol B., Jezierska-Zięba M., Kamieński J., Bełdowicz M., Szpakiewicz M., Soliński J.: Chlorowodorek (2R, 3S)fenyloizoseryny jako półprodukt do otrzymywania Paclitaxelu, Przem. Chem., 2002, 81, 780.

(6) White J. D., Avery M. A., Choudhry S. C., Dhingra O. P., Kang M., White A. J.: Stereocontrolled Synthesis of the C(1)-C(17) Half of Boromycin, J. Am. Chem. Soc., 1983, 105, 6517.
(7) Thangaraj A., Kumar R., Ratnasamy P.: Direct catalytic hydroxylation of benzene with hydrogen peroxide over titanium-silicalite zeolites, Appl. Catal., 1990, 57, L1-L3.

(8) Camblor M. A., Corma A., Martinez A., Perez-Pariente J.: Synthesis of a titaniumsilicoaluminate isomorphous to zeolite beta and its application as a catalyst for the selective oxidation of large organic molecules, J. Chem. Soc., 1992, 8, 589.

(9) Grün M., Unger K. K, Matsumoto A., Tatsumi K.: Novel pathways for the preparation of mesoporous MCM41 materials: control of porosity and morphology, Micropor. Mesopor. Mater. 27, 1999, 207.

(10) Brill W. F.: The Origin of Epoxides in the Liquid Phase Oxidation of Olefins with Molecular Oxygen, J. Am. Chem. Soc., 1963, 85, 141. 